\title{
Relevance Of Ambedkar's Contributions In The Upliftment Of Modern Days Dalits And Women
}

\author{
Dr. Jay Lakshmi \\ Research Scholar, Department of Political Science D. S. College, Katihar-854105, Bihar, India
}

\begin{abstract}
Dalits, a modern term for untouchables in India, are underprivileged people in all social, economic, cultural and political fronts of our society which led to their misery, discrimination, exploitation and oppression by the caste dominated social stratification of India. The Constitution of India classifies Dalits as Scheduled Castes (SCs). They are the people who cultivate the land, mend the shoes, wash the clothes, clean the toilets, scavenge the dead animals or unknown human bodies and do all types of menial works, but share the stigmas of untouchability and are frequently denied the chance to eat, smoke and even seat with the members of upper castes. They often use separate wells and tube wells from those maintained for others. These pitiable conditions of Dalits were seen and addressed by some eminent social and political philosophers like Jyotiba Phule, Mahatma Gandhi, Dr. Bhim Rao Ambedkar and others. Dr. Ambedkar, borne in a poor Dalit family became the first Law Minister of India after independence and the chief architect of Indian Constitution. The text prepared by Dr. Ambedkar provided constitutional guarantees and protection for a wide range of civil liberties for individual citizens. Ambedkar incorporated several Articles in the Indian Constitution for the upliftment of the Dalits and women which included the provision of equal status to Dalits with other segments of society, abolishment of untouchability and discrimination against them, provisions of fundamental rights to all, equal protection of laws, voting rights and reservation in education, jobs, promotion and political fields to them. Besides these several programmes in the form of grants, scholarships, loans, stipend etc. are being provided to Dalits by the States. This is all due to the provisions of Constitution drafted by Dr. Ambedkar. Therefore he may be regarded as the God Father of Dalits in true sense.
\end{abstract}

Keywords : Upliftment, Dalits, Women, Indian Constitution, Articles, Ambedkar

\section{Introduction}

The Dalit question is one of the most important questions in today's political and academic debates in India. The term Dalit has been derived from the Sanskrit root dal which means broken, burst, downtrodden, split, ground-down. It is an expression of the existing contradiction, inequality and exploitation in the Indian hierarchy. The Dalits are considered outcastes falling outside the traditional four-fold Hindu Caste System consisting of the hereditary Brahman, Kshatriya, Vaishya and Shudra classes [1]. Unfortunately they are usually supposed to be impure and polluting and are therefore physically and socially excluded and isolated from rest of the society. Previously they were referred to with different nomenclatures like Chandals, Avarnas, Achhuts, Adidravidia, Depressed classes, Utouchables, Oppressed Hindus, Harijans etc. at different point of time [2,3]. The Constitution of India classified Dalits as Scheduled Castes (Government of India Act 1935). However after the emergence of the Dalit Panther Movement in 1973 they themselves preferred to be called as Dalits in India. Recently the Govt. of Bihar under the leadership of CM Sri Nitish Kumar included 19 castes of Dalits into Mahadalits [4]. Mahadalits are extremely weaker and poorest amongst Dalits. A Dalit is usually a Hindu but it may also be a Buddhist, Sikh, Muslim or Christian [5]. The Caste and analogous systems of social hierarchy also operate across the world particularly in Asia (Nepal, Pakistan, Sri Lanka, Bangladesh, Malaysia and Japan), East South Africa (Kenya, Nigeria, Rwanda, Senegal, Somalia, Mauritius, Fiji, Surinam, the Carribean), UK and North America [6]. Asia remains the continent with the longest share of Dalits.

In 'The Mahan Kosh' Dalits have been defined as one who belongs to the lowest caste or Hini Jati and has been trampled down by or broken under the feet of the Upper Castes or Uchi Jati [7]. According to Gangadhar Pantwane, Dalit is not a caste, but he is a man exploited by the social and economic traditions of his own country. He does not believe in God, rebirth, soul, Holy books teaching separation, fate and heaven because they have made him slave. He does not believe in humanism. Interestingly the category Dalit was used by Ambedkar himself. Ambedkar in his fortnightly Bahiskrit Bharat defines it comprehensively. Dalithood is a kind of life condition which characterizes the exploitation, suppression and marginalization of Dalits by the social, economic, cultural and political domination of the upper caste Brahmanical order [8]. If one takes this view all the exploited and downtrodden producers who have been deprived from the ownership of the means of production, denied basic right of a dignified social life and livelihood, discriminated through biased socioeconomic and political decisions taken in favour of non-producers and privileged classes and kept deliberately 
away from the mainstream of advantages of progress are to be considered Dalits [9]. The recent use of the term Dalit has been developed in the manifesto of Dalit Panther Movement in 1975. Who is Dalit? In this regard this manifesto says members of Scheduled Castes, Scheduled Tribes, Neo-Boddhists, the working people, the landless and poor peasants, women and all those who are being exploited socially, politically, economically and in the name of religion [8]. So Dalits are exclusively the socially and economically marginalized people in India. Now the term Dalit has become a symbol of change and revolution [10].

The pitiable conditions of Dalits were seen and addressed by some eminent, social and political philosophers like Jyotiba Phule, Mahatma Gandhi, Dr. B. R. Ambedkar and others and in their long careers they had taken some ameliorative measures inorder to raise their social status. India after gaining independence enacted different social legislations, to reform the positions of Dalits which included removing the untouchability and discrimination against them and secondly to elevate their status with other segments of the society. As the Chief Architect of Indian Constitution Dr. Ambedkar had a real visionary towards the fundamental rights of Indian Citizens and the underprivileged Dalits in India. He made several provisions in the Constitution to provide constitutional guarantees and protection for a wide range of civil liberties for individual citizens including freedom of religion, the abolition of untouchability and the outlawing all forms of discrimination. The present paper deals with the contribution of Dr. Ambedkar for the upliftment of Dalits and women in India.

\section{Materials And Methods}

The present research is basically an empirical study which is based on the primary as well as secondary sources of information for systematization, analyses and conclusions. About 25 Dalit leaders and 100 Dalit members of Katihar District, Bihar, India was interviewed on the basis of purposive and random sampling method. The interview contained the questionnaire regarding the socio-economic background like profession, education, status of Dalits in the society and their opinion regarding the contribution of Dr. Ambedkar for their upliftment. The Constitution of India, Census of India, relevant books, journals, newspapers, magazines etc. have been made use as secondary sources of data.

\subsection{Plights of Dalits in India}

\section{Results And Discussion}

Dalits represent a community of about 170 million in India constituting about 17\% of the total Indian population [11]. Thus one out of every six Indians is Dalit. Yet due to their caste identity Dalits regularly face discrimination and violence which prevent them from enjoying the basic human rights and dignity promised to all citizens in India. Dalits , a modern term for the untouchables in India are underprivileged people in all social, economic and political fronts of our society which lead to their misery discrimination, exploitation and oppression by the caste dominated social stratification of Indian society. They are the people who usually do the works which are usually not done by the people of Upper Castes either for themselves or for the society. They cultivate the land but they are usually landless, mend the shoes but usually don't wear shoes and clean clothes but usually don't wear clean clothes, clean the toilets but they have no toilets of their own, sweep the buildings and roads but no buildings of their own, they scavenge the dead animals or unknown human bodies but their dead bodies can't be scavenged by the people of higher castes etc. They do all types of menial works which common people usually even avoid to see or throw light on that. They share the stigmas of untouchability and frequently denied the chance from eating with the other caste members, marrying with the other caste members, sinking, playing or even seating with the members of upper castes and using common wells and tube wells utilized by the upper castes (12).

They have separate glasses in village tea stalls, discriminatory seating arrangements and separate utensils in restaurants, segregation in food arrangements in village functions and festivals, prohibited from entering into village temples, prohibited from wearing sandals or holding umbrellas in front of dominant caste members, prohibited from entering into homes of dominant castes, prohibited from riding a bicycle inside the village and prohibited from using common village path. They have separate burial grounds, no access to village's common / public properties and resources (wells, ponds, temples etc.) and separate seating area of their children in schools. Sometimes they have also been prohibited from contesting in elections and exercising their rights to vote, forced to vote or not to vote certain candidates during the elections. If they don't work as their desire they are beaten brutally and even sometimes their houses are burnt. They have been usually prohibited from hoisting the National Flag during Independence Day or Republic Day etc. Usually they get sub-standard wages, work as bonded labourers and face social boycotts by dominant castes for refusing to perform their duties [6]. They are not allowed to use sacred thread at the Vedic site of Upanayan [13]. They live in small broken huts, live dirty, wear dirty clothes and suffer from malnutrition. Due to these features their social, economic, educational and political conditions in our society are still very pitiable.

\subsection{Ambedkar And Dalits}


Dr. Bhim Rao Ambedkar (4 April 1891- 6 December 1956) popularly known as Babasaheb was borne as untouchable in a poor Dalit family which had no right to be an equal in Indian society. Even though he educated himself as one of the most qualified persons of his time [14]. He roused about the humiliation and discrimination of Indian culture to study the law in England and became a respected attorney Indian jurist, political leader, philosopher, anthropologist, historian, orator, economist, teacher, editor, prolific writer, educator etc. He focused his life on defending the untouchables in India, fighting for their legal rights and trying to put an end to the caste system. He wrote a number of essays and books on social inequality. He was of the opinion that the poor needed better educational opportunities as well as greater respect. He always inspired untouchable castes to reject Brahmanical Social Order (BSO) that kept them socially degraded, economically poor, culturally despised, politically powerless and denied them the basic human rights [14]. He challenged the leadership of his time by exposing follies of their proposition of freeing India without freeing millions of untouchables, tribals and socially and educationally backward classes living in sub-human conditions under the socio-economic administration of the Hindus. As the Chief Architect of free India's new constitution he abolished all forms of discrimination and inequalities based on caste, gender, race or status [15]. Despite his record of scholarship, his legal colleagues and others of the upper class of Hindu society refused to treat him as equal, so he eventually converted to Buddhism, but he never stopped fighting to improve the lives of the poor and the outcastes in India.

As the First Law Minister of India, Dr. Ambedkar for the first time really tried to defend the women of India specially the weaker sections in the form of Hindu Code Bill on $11^{\text {th }}$ April 1947. The Bill has the provisions for several basic rights to women. It attempted to establish monogamy as the only legal system and abolish different marriage systems prevalent among the Hindus. Its main aim was to ferment the right to property and adoption of women. It provided for restitution of conjugal rights and judicial separation. It sought to unite the Hindu Code with progressive and modern thought [15]. This Bill invited strong opposition from the Hindu Orthodoxy in post independent India in 1948 when Hindu Code Bill was introduced in Parliament and debated on the floor of the House. Ambedkar tried his level best to defend the Bill by pointing out the drawbacks of Indian Society and arguing that the ideals in the Bill are based on the constitutional principle of equality, liberty and fraternity. However the Bill could not withstand the opposition of Hindu orthodoxy. Their major argument was that the Bill will demolish the entire structure and fabric of Hindu Society. Finally in 1951 PM J. L. Nehru dropped the Bill by saying that there was too much opposition. On this issue the then Law Minister resigned for the cause of the disadvantaged.

\subsection{States Measures for Dalit Upliftment by Ambedkar}

After independence Dr. Ambedkar became the First Law Minister of nation. He was appointed as Chairman of the Constitution Drafting Committee by the Assembly to write India's new constitution. The text preparted by Ambedkar provided constitutional guarantees and protection for a wide range of civil liberties for individual citizens including freedom of religion, the abolition of untouchability and outlawing all forms of discrimination. He had a real visionary towards the fundamental rights of Indian citizens and upliftment of Dalits. He made several provisions in the form of Articles in the Constitution for the upliftment of the Dalits.

Dr. Ambedkar introduced Article 13(2) which describes - "The State shall not make any law which takes away or abridges the rights conferred by this part and any law made in this contravention of this cause shall, to the extent of the contravention, be void". Article 14 of the Constitution declares that "the State shall not deny to any person equality before the laws or equal protection of laws". Article 15 of the Indian Constitution gives "fundamental rights to all Indian Citizens against any form of discrimination either by State or by any citizen on the basis of religion, race, caste, sex, place of birth or any of them". Article 15(4) of the Constitution of India declares that "Nothing can prevent the State from making any special provision for the advancement of any socially and educationally backward classes of citizens or for the Scheduled Castes (SCs) and the Scheduled Tribes (STs)". Atrticle 16(4A) declares that "Nothing can prevent prevent the State from making any provision for reservation in matters of provision with consequent seniority to any class or classes of posts in the services under the State in favour of SCs and STs which in the opinion of the State are not adequately represented in the service under the State". Article 16(4B) states that "Nothing in the Article shall prevent the state from considering any unfilled vacancies of year which are reserved for being filled in that year in accordance with any provision for reservation made under clause (4) or clause as a separate class of vacancies shall not be considered together with the vacancies of the year in which they are being filled up for determining the ceiling of 50\% reservation on total number of vacancies of the year". Article 17 of the Indian Constitution declares that " Untouchability is abolished and its practice in any form is forbidden. The enforcement of any disability arising out of untouchability shall be an offence punishable in accordance with law". Based on this Article the Civil Right Protection Act 1965 and the Prevention of Atrocities (SCs and STs Act 1989) was enacted by the Parliament for the protection of Dalit rights. 
Article 330 of the Indian Constitution declares reservation of seats for Scs and STs in the House of the People for Scheduled Castes, Scheduled Tribes except some STs in the autonomous districts of Assam and Scheduled Tribes in the autonomous districts of Assam. Article 332 in the constitution of India states about the reservation of seats of SCs and STs in Legislative Assemblies of the States. 73rd amendment of constitution in the Article 243 declares that "Panchayat bodies must have proportionate representation of SCs and STs and women. Such reservation should also apply in the case of Chairperson and Deputy Chairpersons of their bodies". Besides these several programmes of the Indian State in the form of grants, scholarships, loans, stipends etc. are being provided for Dalits. This is all due to provisions of constitution drafted by Dr. Ambedkar. He was really a God Father for the Dalits in true sense.

\subsection{Situation of Dalits after 66 Years of Independence}

Dr. B. R. Ambedkar had a real visionary towards the upliftment of Dalits. His main aim was to uproot the evil of deep-rooted caste system, uplift the status of downtrodden society, create honour amongst so called upper castes and to transform this country from uncivilized state to civilized state. By fighting against English rulers and including Articles in the constitution he tried his best to enable Dalits and women to the present day developed state. Before independence the social, economic and political conditions of Dalits and women were very grim. Today we find all round development of disadvantaged groups in India [16]. Untouchability has reduced, their socio-economic and political status have improved. Today Dalits have become a powerful political force in India and enjoy greater access to education and economy than ever before. They are exercising their voting rights. Their political consciousness and awareness about various political activities and participation in these activities have increased very much. Due to these facts now-a-days the Govt. is also making various decisions relating to their rights and privileges. Efforts are still going on to remove different discriminatory practices against them [3]. Now votes of the Dalits have become one of the major deciding factors for winning of a candidate or a political party in elections. The honours for Dalits in high caste society have also increased. Today we do not ask the person seating besides us which caste he belongs to? Today at least in towns both Dalits and non-Dalits enjoy the same tea stall, hotel and cinema hall but usually no body bothers about knowing the caste identity of a person. This is all due to the un-tired and intelligent efforts of Dr. Ambedkar.

But it does not mean that the untouchability has totally abolished. Still it is maintained in offices, colleges, ceremonies etc. Today's tragedy is that the rulers of our nation do not want the effective implementation of constitution. There is a far gap in between their sayings and workings. Manu introduced caste system in India. Dr. Ambedkar introduced caste annihilation system in India. Indian Hindu orthodoxy stood by Manu. Ambedkar stood for Dalits and women developments in India. Ambedkar defeated Manu through Constitution by incorporating several Articles in it. Ambedkar was successful in fixing the Hindu orthodox people's attitude and behaviour as enshrined in their holy books towards others as unjust and punishable through various provisions in the India's Laws and Constitution [15].

Recently an eminent sociologist, Pritish Nanda in Jaipur Literature Festival, 2013 blamed that SCs and STs were mainly responsible for corruption in India [17]. This is a totally irrelevant, irresponsible and unjust statement which caused a great controversy between Dalits and non-Dalits. This shows the prejudiced mentality of the so called elite society people. Are the people of Upper Caste are not corrupt? The question arises who are making SCs and STs corrupt? Who have taught the lessons of purchase - sail to the leaders of SCs and STs? The rulers of Upper Caste people are basically responsible for corruption in the society because all the dominating administrative powers and forces of society are retained within them. However, unfortunately sometimes the Sc and ST peoples who are duly established in the society, misuse the rights given to them. A special type of power demonstration is expressed indirectly by them. They try to demonstrate their special power and unity in the society due to the privileges which they obtain from the laws, sovereignty, rules and administration. Is the misuse of power, posts and sovereignty not possible by these power effluent and legally supported people? [18].

\section{Conclusion}

The Constitution of India provides equal rights to all its citizens right to live with equality, honour and dignity. But the caste system and untouchability somehow and others are still playing negative roles from different parts of the society. Untouchability is a crime against humanity. Untouchability against mehtar/dom sub-caste of Dalits is still prevalent in our society which is inhumane. Hence it is the right time to adopt the principles of Dr. Ambedkar. The Constitution of India is designed in such a way that all its citizens are equal before it. Our nation is facing different sorts of socio-economic, educational and political evils in the society and only the effective implementation of Constitution in its real spirit can overcome them. The Dalits also will have to come forward and to labour hard in all social, economical, educational and political fields to compete with the other members of the society. They should avoid power demonstration and enjoy their rights properly. Each 
Dalit member will have to try to become a Second Ambedkar. God has created the entire creature including human beings without caste identity. It is we who make all these discriminations. So the people of advanced classes will have to change their mentality. They will have to be more generous towards the Dalits regarding untouchability and the upliftment of their socio-economic, educational and political status etc. by accepting them as equal humans like themselves. The social structure of our society is based primarily on them because they are the people who perform all types of menial works which are usually avoided by the people of elite class. Without them no society has run previously, not running now and will not run in future.

\section{Acknowledgement}

Author is thankful to Dr. Pawan Kumar Jha, Prof. and Head, Dept. of Political Science , D.S. College, Katihar , Bihar, India for providing important suggestions, relevant literature and books in the preparation of this text.

\section{References}

[1] Oman, John Campbell (2003). Religious Festivals and Caste System in India. Khanna Publishers, New Delhi, p. 42

[2] Kumar, Vivek (2005). Situating Dalits in Indian Society. Sociological Bulletin, 54(3), Sep.-Dec. p. 514.

[3] Kumar, Lalan (2012). Political Participation of Dalits in Punjab : A Comprehensive Study of Navanshehar and Patiala districts. Introduction, Ph. D. Thesis.

[4] State Mahadalit Commission (2007). SC and ST Welfare Department of Bihar.http://mahadalitmission.org/BMVMIntroduction.php\#EWEU9aKwLa.

[5] Wikipedia (2013). Dalit. Wikipedia, the Free Encyclopedia. Wikimedia Foundation Inc., a non-profit organization..http://en.wikipedia.org/wiki/Dalit.

[6] NCDHR (2013). Who are Dalits and What is Untouchability? Dalits and Untouchability. Media Library Publications, New Delhi.

[7] Nabha, Bhai Kahan Singh (1930). Mahan Kosh, (Encyclopedia of Sikh Literature). Language Department, Patiala, Punjab, p. 468.

[8] Guru, Gopal (1998). The Politics of Naming. Seminar, No.471, Nov., p. 16.

[9] Diwakar, D.M. (1999). Dalit Question of Inequality, Exploitation and Movilization : A Micro Viewof Ground Realities. Man and Development, Vol. XXI, No. 3, September, p. 63.

[10] Zelliot, Eleanor (1992). From Untouchable to Dalit : Essay on the Ambedkar Movement, Manohar Publications, New Delhi, p. 268.

[11] Census (2011). Census of India. Govt. of India, Ministry of Home Affairs, Office of the RegistrarGeneral \& Census Commissioner, India.

[12] Juergensmeyer, Mark (1988). Religious Rebels in the Punjab : The Social Vision of Untouchability. Ajanta Publications, Delhi.

[13] Rajadhakshya, Ranjit (2004). Encyclopaedia of Social Problems and Social Change. Dominant Publishers, New Delhi, p. 235.

[14] Bharati, A.K. (2001). Dr. Ambedkar's Vision for Dalit Upliftment :Extract from a Souvenir. NationalConference on Dalit Organizations, New Delhi. Centre for Alternative Dalit Media (CADAM),Delhi.

[15] Navayan, Karthik (2012). Dr. Ambedkar Contribution in Law and Justice for the Upliftment of the Disadvantaged. National Seminar on Ambedkar's Contribution for the Upliftment of the Disadvantaged. $2^{\text {nd }}$ and $3^{\text {rd }}$ September, 2010, seminar Hall, MGNIRSA.

[16] Michael, S.M. (2007). Dalits in Modern India : Vision and Values. Sage Publication.

[17] Urmilesh (2013). Illogical statement on Dalit Philosophy. Dainik Jagran, Daily Hindi News Paper, Bhagalpur, City edition, Year 1, Issue 212, 02 February 2013, p.12.

[18] Sengar, Kumarendra Singh (2013). Statement of Ashish Nandi, Dainik Jagran, Hindi News Paper, Bhagalpur, City edition, Year 1, Issue 212, 02 February 2013. http://bit.ly/WAohbN. 